\title{
Ethiopia's FDI inflow from India and China: analysis of trends and determinants
}

\author{
Degele Ergano ${ }^{1,2^{*}}$ and K. Rambabu ${ }^{3}$
}

\section{${ }^{*}$ Correspondence:}

degela1997@gmail.com

2 Department of Economics,

Hawassa University, Awassa, Ethiopia

Full list of author information is available at the end of the article

\begin{abstract}
This study analyzes the trends and determinants of FDI inflow to Ethiopia from India and China. It is based on panel data of 2 decades (1997-2016). It employs a gravity model approach and fixed effects estimation technique to identify factors governing the flow of FDI to Ethiopia. Factors affecting the flow of Indian FDI to Ethiopia include Ethiopia's trade with India, India's population size, GDP of Ethiopia, GDP PC of India, real interest rate, credit access and FDI openness in Ethiopia. Similarly, factors governing Chinese FDI flow to Ethiopia include Ethiopia's GDP growth, Ethiopia's trade with China, FDI openness and secondary school enrolment. Government expenditure in the host country reduces China's and India's FDI inflow. The traditional explanatory variable, a resource rent, is not found significant in explaining FDI in flow from China and India. The FDI inflow from India and China showed an increasing trend with an average rate of $82 \%$ and $202 \%$, respectively, during the two-decade period. But the overall trend for both partner countries showed fluctuation across years. We can conclude that FDI from India is responsive to macroeconomic variables such as OER, real interest rate and liberalization measures such as trade openness in Ethiopia. FDI and trade flows from China are positively related to one another and cheap labour is an important attraction factor for Chinese FDI inflow. Policy makers in Ethiopia can focus on macroeconomic reform in case of the country's relation with India whereas they focus on maintaining cheap labour cost, GDP growth and trade transactions with China.
\end{abstract}

Keywords: China, Determinants, FDI, India, Gravity model, Trends, Panel data

\section{Introduction}

\subsection{Background}

According to WB estimates, Ethiopia is one of the fast-growing African economies with an average growth record of $10.6 \%$ for the past one and half decades (World Bank Group 2016). Ethiopia's growth was induced by factors including agricultural modernization; development of new export sector; strong global demand for commodities and Government led development investments (WB 2012). Currently, the Government of Ethiopia is implementing its second phase Growth and Transformation Plan (GTP-II) for the period of 5 years (2015/16-2019/20) with an aim of transforming the country into a manufacturing hub (World Bank Group 2016). The country is the host of the second largest population in Africa with the population size of 99.39 million in 2015, according to the WB population estimates.

(c) The Author(s) 2020. This article is licensed under a Creative Commons Attribution 4.0 International License, which permits use, sharing adaptation, distribution and reproduction in any medium or format, as long as you give appropriate credit to the original author(s) and the source, provide a link to the Creative Commons licence, and indicate if changes were made. The images or other third party material in this article are included in the article's Creative Commons licence, unless indicated otherwise in a credit line to the material. If material is not included in the article's Creative Commons licence and your intended use is not permitted by statutory regulation or exceeds the permitted use, you will need to obtain permission directly from the copyright holder. To view a copy of this licence, visit http://creativeco mmons.org/licenses/by/4.0/. 
China with its second largest economic size is becoming the global game changer with an increasingly important role in Africa's investment in general and Ethiopia's FDI inflow in particular. Similarly, India, which was ranked as the 8th largest economy in real GDP terms in 2013 by WB GDP statistics, is one of the fast-changing global economies with its significant role in Africa in general and Ethiopia in particular through its FDI flow and trade relations.

Sino-Ethiopia economic cooperation began in early 1970s but the relationship got momentum after 1995 with the establishment of Joint Ethio-China Commission (Gedion 2014). Ethio-India economic relation began in 1948 but it witnessed a significant progress only after 1991, the year in which economic liberalization was introduced in Ethiopia. The relationship was further strengthened with the establishment of Bilateral Investment Promotion and Protection Agreement (BIPPA) in 2007 (Prateeksha 2015).

FDI does not comprise a major component of external finance inflow to low-income countries, but becoming increasingly important with the rise of China and India (Kinfu et al. 2010). FDI is important to sustain high investment rates and is essential for knowledge and technology transfer. Hence, attracting FDI is generally considered as an integral part of the development policy mix of successful emerging economies.

Ethiopia's cheap and abundant labour, privileged access to high-income markets and growing domestic and regional markets add to its attraction as an FDI host country. But looking at the FDI levels (in \% of GDP) currently observed in Ethiopia and in comparison to the successful East Asian countries, it is clear that there is an opportunity to improve the promotion of incoming FDI (WB 2012). FDI as a \% of GDP in Ethiopia has been at a relatively low level of $2.0 \%$ between 2004 and 2014 somewhat contrasted by $3.9 \%$ of GDP in China for years 1991-2010 (Prateeksha 2015).

But the country's FDI stock has been increasing since 1995 and the country has become one among the best 10 destinations in Africa (Dejene 2016). Currently, it is the 3rd largest FDI recipient in Africa. FDI flow to Ethiopia was \$146.6 million in 1997 and yearly FDI inflow has varied between \$146.6 million and \$977 million between 1997 and 2016. This is in part because the Ethiopian Industrial Strategy is attracting Asian capital to develop its manufacturing base. Indeed FDI in light manufacturing from China, Turkey and India is the major cause of the increase in FDI inflow to Ethiopia (Selamawit Berhe 2015).

In the last few years, India and China have emerged as top foreign investors in Ethiopia and there is an increasing significance of FDI in Ethiopian economy, thus with an increasingly important role for India and China to play in Ethiopia's development process (Prateeksha 2015).

Despite an agricultural exporter, Ethiopia has attracted significant volume of FDI from China. China's FDI inflow to Ethiopia averaged at $\$ 88.5$ million every year for the period 1997-2016 with an average growth at 202\%. Similarly, India's FDI inflow to Ethiopia averaged at $\$ 40.9$ million every year for the two-decade period with an average growth of $82 \%$. (Own analysis from Ethiopian Investment Commission data).

China's and India's manufacturing FDI in Ethiopia is still smaller in size than its potential. What policy change can help the Ethiopian Government to attract more Chinese and Indian manufacturing investment and benefit from it is a question of concern. It would be of great importance to know what factors encourage the flow of FDI from the 
emerging Asian giants and what policy measures could help in this regard. Hence, the objective of this research is to examine the major factors governing the FDI inflow from China and India to Ethiopia.

\subsection{Literature on FDI relation of Ethiopia with China and India}

FDI is defined as an investment involving a long-time relationship and reflecting a lasting interest and control of a resident entity in an economy other than that of the foreign direct investor. It includes three components such as equity capital; re-invested earnings and intra-company loans (Anne-Lise 2014). It is conventionally defined as a form of internal inter-firm cooperation that involves a significant equity stake in or effective management control of host country enterprises (Qian, et al. 2002, pp. 4).

The main theoretical research on motivation for FDI are the production Cycle Theory by Raymond Vernon; the Internationalization Theory by Stephen Hymer and the Eclectic Paradigm by John Dunning (Anne-Lise 2014).

\subsubsection{Theories on investment behaviour}

The few theoretical models at work that explain investment decision behaviour in literature include the Accelerator, the Liquidity, the Expected Profits also known as the Cash Flow or Tobin's q and the Neoclassical models of investment behaviour (Mekonnen 2010).The author in his study on private investment in Ethiopia briefly put the theories as follows:

The Accelerator theory of investment explains that investment decision of a firm is determined by changes in demand for its produces and the main implication of the model is that the investment expenditure of an investing firm is proportional to its output while its output is a function of demand (Song et al. 2001, p. 229).

The Liquidity theory of investment behaviour proposes desired capital to be proportional to the internal fund (liquidity) available for investment.

The Expected Profits (Cash Flow) theory of investment explains desired capital as a proportion of the market value of a firm. The model is regarded as a generalization of the Expected Profits model in which investment expenditure is related to the ratio of the market value of business capital assets to the replacement value of those assets. This ratio is known as Tobin's $q$. According to the model, a value of $q$ closer to 1 or greater encourages investment while a lower value of $q$ discourages it.

The Neoclassical theory of investment behaviour equates desired capita stock to the value of output deflated by the price of capital services including or excluding capital gains. At the core of this model is the importance of the value of output in influencing investment decisions; thus, it is regarded as a version of the flexible accelerator model (Salahuddin and Islam 2008, p. 21-22).

The theory of multinational enterprises develops its arguments by concentrating on two questions: The issue of internalization, that is, replacement of firms' external contracts by direct ownership due to market imperfections and the question of location, which is diversity related to the links between flows of goods and factors, that is, to locate the different activities and organizational units in a specific region (Zarotiadis n.d.). 
A brief review of relevant empirical literature is done on FDI inflows specifically from China and India to Ethiopia to examine the trends and determinants of the emerging relation.

\subsubsection{To summarize the overall context of the FDI literature}

FDI links from the Asian Giants to Ethiopia are considered a win-win and mutually beneficial by Nazgol (2014); Gebregeorgis (2016); Asayegn (2009); Malancha (2014), etc. On the other hand the links have both opportunities and threats and there are winners and losers in the game in the host country and the outcome depends on the actors and host country's extra collaborative engagements. These studies include Tegegne (2006), Dawit (2014), and Alemayehu and Atnafu (2011).

The studies identified determinants of FDI flow from China and India to Ethiopia as follows: Trade openness (+ve), Inflation (-ve), Labour cost (+ve), Host country economic size (+ve), Presence of Government SEZ (+ve), Political instability (-ve), Investment climate $(+v e)$, Economic growth $(+v e)$, real GDP growth $(+v e)$, Policy incentive $(+\mathrm{ve})$, Market size $(+\mathrm{ve})$, Returns to Investment $(+\mathrm{ve})$, Infrastructure $(+\mathrm{ve})$, Foreign exchange instability (-ve), Government expenditure (+ve and $-\mathrm{ve})$, GDP PC (-ve), Natural Resource (+ve).

Of the 10 most relevant articles identified for FDI relation of the Asian giants with Ethiopia, none of them used a methodology based on gravity model and panel data frame work for their studies.

\subsection{Methodology}

The flow of FDI to Ethiopia is analyzed descriptively and comparatively in the first section based on 20-year FDI inflow data obtained from Ethiopian Investment Commission.

The second part of the analysis used gravity model-based fixed effects estimation techniques to examine the major explanatory variables for FDI inflow from China and India to Ethiopia.

\subsubsection{The gravity model: theoretical formulation for trade and FDI flows}

Gravity model is used in explaining the bilateral economic relations between countries for their bilateral trade and FDI flows. It is considered as a common work-horse in international trade and factor flow analysis (Eichengreen 1998).

Many gravity model applications intend to project bilateral trade (and more recently also FDI) relations between countries (Peter 2000; Estrella, Juliette n.d.).

Gravity equation is analysed in the light of a partial equilibrium model of export supply and import demand for the rationalization according to Linnemann (1966). Anderson (1979) also derives the gravity model which proposes identical Cobb-Douglas or constant elasticity of substitution (CES) preference functions for all economies and weakly separable utility functions between traded and non-traded goods and investment flows.

Further rationalization for the gravity model approach is based on the Walrasian general equilibrium model, which states that each country has its own supply and demand functions for all goods. The factor of aggregate income determines the level of demand in the importing country and the level of supply in the exporting country (Oguledo and Macphee 1994). While Anderson's analysis was at the aggregate level, Bergstrand 1989) 
developed a microeconomic foundation to the gravity model. He explained that a gravity model is a reduced form equation of a general equilibrium of demand and supply systems. Bergstrand argues that since the reduced form eliminates all endogenous variables out of the explanatory part of each equation, income and prices can also be used as explanatory variables of bilateral trade or FDI. The resulting model is termed a "generalized" gravity equation (Krishna 2002). Eaton and Kortum (1997) have also derived the gravity equation from a Ricardian framework, while Deardorff (1998) derived it from a Hecksher-Ohlin perspective.

Gravity Model of International Trade was initially developed by Tinbergen in 1962 (Hui and Howard 2005). It utilises the gravitational force concept as analogy to explain the volume of trade, capital flows and migrations amongst countries. Newton gravity model states that the interaction between two heavenly bodies is proportional to the product of their masses and inversely related to the distance between them (Dinh et al. 2010).

$$
G F_{i j}=M_{i} M_{j} / D_{i j}
$$

where $M$ is mass and $D$ is distance for countries $i$ and $j$.

In the form of natural log:

$$
\log G F_{i j}=\ln M_{i}+\ln M_{j}-\ln D_{i j} ; \quad \text { where } i \neq j .
$$

The Gravity Model of Bilateral Trade (FDI) in its basic form states that trade(FDI) flow between country $i$ and $j$ is proportional to the product of $G D P_{i}$ and $G D P_{j}$ and inversely related to the distance between them (Santos and Silvana 2006).

$$
F_{i j}=\alpha_{o} Y_{i}^{\alpha 1} Y_{j}^{\alpha 2} D_{i j}^{\alpha 3},
$$

where $\alpha_{\mathrm{o}}, \alpha_{1}, \alpha_{2}$ and $\alpha_{3}$ are unknown parameters; $F_{i j}=$ Flow of factors.

To account for deviations from the theory, stochastic versions of the equation are used in empirical studies. Typically, the stochastic version of the gravity equation has the form:

$$
F_{i j}=\alpha_{\mathrm{o}} Y_{i}^{\alpha 1} Y_{j}^{\alpha 2} D_{i j}^{\alpha 3} \eta_{i j}
$$

$\eta_{i j}=$ is an error factor, assumed to be statistically independent of the regressors.

There is a long tradition in the trade/FDI literature of log-linearizing Eq. (4) and estimating the parameters of interest by least squares, using the equation

$$
\operatorname{Ln} F_{i j}=\ln \alpha_{\mathrm{o}+} \alpha_{1} \ln Y_{i}+\alpha_{2} \ln Y_{j}+\alpha_{3} \ln D i_{j}+\ln \eta_{i j} .
$$

\subsubsection{Estimation techniques}

Estimation techniques for bilateral Trade and FDI flows applicable to a panel data frame include Pooled OLS, Fixed Effect Estimators, Random Effect Estimation, Hausman Test, OLS Estimation of Double log, etc., can be used as an estimation technique (Davidova 2012). 
Other methods include Poisson Pseudo-Maximum Likelihood (PPML), Threshold Tobit, Least Square Dummy Variable (LSDV), Generalized Methods of Moments, Classical Minimum Distance Estimation Techniques, and Heckman Estimation Technique.

\subsubsection{Fixed effect estimator}

Fixed Effect approach is preferred here because it has one considerable advantage over random effects estimation. That is, little justification for treating the individual effect as uncorrelated with regressors as is assumed in the random effect model.

Random Effects model may suffer from the inconsistency due to the correlation between the individual variables and the random effect. However, the random effects treatment does allow the model to contain observed time-invariant characteristics such as demographic while fixed effect model does not (Estrella, Juliette n.d.). Fixed Effect estimation assumes that the unobserved heterogeneity component in the regressors is constant overtime.

If $Z$ is unobserved, but correlates with $X i t$, then the least square estimator of $\beta$ is biased and inconsistent as a consequence of an omitted variables. In such instances we use fixed effects estimators:

$$
\text { Yit }=\text { Xit } \beta+\alpha \mathrm{i}+\varepsilon \text { it, }
$$

where $\alpha i=Z i^{\prime} \alpha$, embodies all the observable effects and specifies an estimable conditional mean.

This approach takes $\alpha$ i to be a group-specific constant term. It is fixed because the term does not vary over time.

More over this study focuses in indentifying with-in variability of the FDI inflow between a bilateral pair country (Fixed effects estimation) not between the different pair of countries which demands use of random effects estimation.

\subsubsection{Panel data frame work}

Green Econometrics (2002) recommends panel data models compared to cross-section for trade/factor flow analysis. Panel data allow the researcher greater flexibility in modelling difference in behaviour across individual countries.

A panel data framework reveals several advantages over cross-section analysis. It allows to capture the relationships between the relevant variables over a longer period and to identify the role of the overall business cycle phenomenon.

Through a panel approach one is able to disentangle the time-invariant country-specific effects. Above all, one should take into account that the interpretation of the estimated coefficients which is crucially different from that of cross-section analysis. In a panel framework, one checks for cross-section deviations and is thus able to interpret the parameters as elasticity of the influence of independent variables on the dependent one.

\subsubsection{Empirical investigation of the FDI determinants}

The inflow of FDI to Ethiopia from the two emerging Asian economies (China and India) is analysed using Panel data for the years ranging from 1997 to 2016 . The data 
are obtained from domestic institutions such as Ethiopian Investment Commission and international institutions such as IMF, UNCTAD and WB.

The method employed for the analysis of determinants of FDI inflow to the host county is Fixed Effect Estimation. The driving factors for the emerging partners' increased presence are examined using gravity model.

The dependent variable in our analysis is FDI inflow from China and India to Ethiopia. Explanatory Variables would include demographic, geographic and macroeconomic variables. The regression takes the functional form for some of the regressors as follows:

$$
\text { Lnfdiflow }=\beta_{1}+\beta_{2} \text { lnettrad }+\beta_{3} \text { Infornpopn }+\beta_{4} \text { lnetgrowth }+\beta_{5} \text { Inresource }+ \text { Wit, }
$$

where Lnfdinflow $=\log$ of FDI inflow; Lettrade $=\log$ of Ethiopia's bilateral trade; Lnfornpopn $=\log$ of Foreign Population; Lnetgrowth-log of Ethiopia's GDP growth; Lnresource $=\log$ of Resource rent in Ethiopia; Wit $=$ the Error term; $\beta_{1}=$ the intercept term; $\beta_{2}, \beta_{3}, \beta_{4}, \beta_{5}=$ elasticity of explanatory variables.

\section{FDI inflow to Ethiopia from India and China}

\subsection{Descriptive statistics: Trend analysis}

India's FDI flow to Ethiopia for the last 20 years has been analyzed in Table 1. Annual average flow for the 20 years was $\$ 40.9$ million and the average FDI inflow growth was found $82.04 \%$. The FDI inflow from India has had the value share at $0.16 \%$ of Ethiopia's GDP and $9.48 \%$ of India-Ethiopia trade for the period under study. The FDI flow from India amounts to $10 \%$ of the bilateral trade flows between Ethiopia and India, and the largest share of 30\% was recorded in the year 2003 (Table 1).

Table 1 Different ratios related to Ethio-India FDI flow. Source: Own analysis

\begin{tabular}{|c|c|c|c|c|c|c|c|}
\hline Year & FDI in flow & FDI \% growth & Et GDP & FDI/GDP & Et-India trade & $\begin{array}{l}\text { India FDI/ } \\
\text { Trade }\end{array}$ & Et. Popn \\
\hline 1997 & $1,458,954$ & & $8,589,211,391$ & 0.02 & $62,784,663$ & 2.32 & $60,976,450$ \\
\hline 1998 & $2,985,107$ & 104.6 & $7,818,224,906$ & 0.04 & $81,953,062$ & 3.64 & $62,794,151$ \\
\hline 1999 & $1,409,658$ & -52.8 & $7,700,833,482$ & 0.02 & $64,923,910$ & 2.17 & $64,640,054$ \\
\hline 2000 & 402,908 & -71.4 & $8,242,392,104$ & 0.00 & $74,113,215$ & 0.54 & $66,537,331$ \\
\hline 2001 & $3,701,381$ & 818.7 & $8,231,326,017$ & 0.04 & $116,995,551$ & 3.16 & $68,492,257$ \\
\hline 2002 & $11,470,402$ & 209.9 & $7,850,809,498$ & 0.15 & $113,056,072$ & 10.15 & $70,497,192$ \\
\hline 2003 & $38,692,154$ & 237.3 & $8,623,691,300$ & 0.45 & $183,016,622$ & 21.14 & $72,545,144$ \\
\hline 2004 & $44,936,340$ & 16.1 & $10,131,187,261$ & 0.44 & $199,949,128$ & 22.47 & $74,624,405$ \\
\hline 2005 & $45,391,754$ & 1.0 & $12,401,139,454$ & 0.37 & $257,906,696$ & 17.60 & $76,727,083$ \\
\hline 2006 & $63,556,152$ & 40.0 & $15,280,861,835$ & 0.42 & $323,647,069$ & 19.64 & $78,850,689$ \\
\hline 2007 & $43,506,872$ & -31.5 & $19,707,616,773$ & 0.22 & $436,868,096$ & 9.96 & $81,000,409$ \\
\hline 2008 & $191,789,492$ & 340.8 & $27,066,912,635$ & 0.71 & $644,865,555$ & 29.74 & $83,184,892$ \\
\hline 2009 & $160,032,513$ & -16.6 & $32,437,389,116$ & 0.49 & $648,721,772$ & 24.67 & $85,416,253$ \\
\hline 2010 & $55,546,889$ & -65.3 & $29,933,790,334$ & 0.19 & $644,732,819$ & 8.62 & $87,702,670$ \\
\hline 2011 & $37,003,849$ & -33.4 & $31,952,763,089$ & 0.12 & $800,666,714$ & 4.62 & $90,046,756$ \\
\hline 2012 & $27,679,051$ & -25.2 & $43,310,721,414$ & 0.06 & $1,114,961,538$ & 2.48 & $92,444,183$ \\
\hline 2013 & $29,339,234$ & 6.0 & $47,648,211,133$ & 0.06 & $1,260,183,940$ & 2.33 & $94,887,724$ \\
\hline 2014 & $12,329,326$ & -58.0 & $55,612,228,234$ & 0.02 & $1,109,234,876$ & 1.11 & $97,366,774$ \\
\hline 2015 & $14,821,212$ & 20.2 & $64,464,547,915$ & 0.02 & $1,216,407,420$ & 1.22 & $99,873,033$ \\
\hline \multirow[t]{2}{*}{2016} & $32,365,833$ & 118.4 & $72,374,224,249$ & 0.04 & $1,370,287,325$ & 2.36 & $102,403,196$ \\
\hline & Tot $=818,419,081$ & $A v=82.04$ & 519378082140 & $A v=0.0016$ & Av growth $=19.7$ & $A v=9.48$ & FDI pc 0.495 \\
\hline
\end{tabular}


Table 2 India's FDI inflow to Ethiopia by investment type, 1997-2016. Source: Own analysis from Ethiopian Investment Commission data

\begin{tabular}{llll}
\hline R. no. & Investment type & Number of projects & $\%$ \\
\hline 1 & Manufacturing and construction & 402 & 69.79 \\
2 & Agriculture and allied activities & 97 & 16.84 \\
3 & IT and related activities & 15 & 2.60 \\
4 & Education services & 10 & 1.74 \\
5 & Health services & 6 & 1.04 \\
6 & Hotel and resort services & 6 & 1.04 \\
7 & Other services & 40 & 6.94 \\
Total & & 576 & 100 \\
\hline
\end{tabular}

Table 3 Regional distribution of Indian FDI Projects in Ethiopia, 1997-2016. Source: Own analysis from data of Ethiopian Investment Commission

\begin{tabular}{llcc}
\hline R. no. & Region & Number of projects & $\%$ \\
\hline 1 & Addis Ababa & 258 & 44.79 \\
2 & Oromia & 210 & 36.46 \\
3 & Amahara & 24 & 4.17 \\
4 & SNNPRS & 20 & 3.47 \\
5 & Gambella & 10 & 1.74 \\
6 & Dire Dawa & 8 & 1.39 \\
7 & Tigray & 8 & 1.39 \\
8 & Harari & 1 & 0.17 \\
9 & Afar & 1 & 0.17 \\
10 & Multiregional & 32 & 5.56 \\
& Total & 576 & 100 \\
\hline
\end{tabular}

The sectoral distribution of Indian FDI in Ethiopia is shown in Table 2. There are 576 projects of Indian origin for the years under study (Table 2).

Of these 576 FDI projects, 402 (69.79\%) were engaged in manufacturing and Construction sectors and 97 (16.84\%) were engaged in agriculture and allied activities, $15(2.6 \%)$ in IT and related services, $10(1.74 \%)$ in educational services, $6(1.04 \%)$ in health services, and 46 (6.94\%) were engaged under miscellaneous categories.

The distribution shows that Indian firms are engaged more in manufacturing and construction followed by agricultural investments in Ethiopia.

Table 3 describes the regional distribution of Indian FDI in Ethiopia. Indian firms were distributed across regional states and urban centres for the years under study. 258 (44.79\%) of the FDI projects were located in Addis Ababa, the capital city of the country followed by 210 (36.46\%) Oromiya Regional State. Amhara, SNNPRS, and Gambella follow the distributional order with number of projects 24 (4.1\%), 20 (3.47\%), and 10 (1.47\%), respectively. Diredawa and Tigray each consisting of 8 FDI projects and other $32(5.56 \%)$ of the projects were multi-regional in nature (Table 3 ).

The distribution of Indian FDI projects in Ethiopian Regional States was uneven. The major reason for this uneven distribution may be geographic proximity to market and easy access for infrastructure and related services. Oromia and Addis Ababa are 
both at the centre of economic transaction or market access, and hence, were preferable for investors.

According to information from the Indian Embassy Ethiopia home page, there were more than 30 major investing firms engaged in Ethiopia, the list of which includes MSP steel and power limited, Arvind Envisol, Balaalji Manufacturing PLC, Aarti Steel PVT Ltd. Co, Sonalika Tractors, Kanoria Africa Textiles plc, Raymond, Cadila Pharmaceuticals plc, S and P Energy Solutions plc, Tata International limited, Karuturi Global plc, Mohan Group of Companies, Anmol products Ethiopia plc, Telecommunication Consultants India Limited (TCIC), Exim Bank of India, Oxford Group of Companies, Roto plc, Whitefield Cotton Farm, Ruchi Agri plc, Verdanta Harvests plc, Neha International plc, Asian Paintings, Arvind Mills, Allana Sons ltd, SVP Group, Fontana Flowers plc, Samaka Stones PVT Ltd. Co, Velocity Apparels, etc.

China is the leading FDI source for Ethiopia with its share at 24.4\% (Own analysis from Ethiopian Investment Commission data).

When we see Table 4, Chinese FDI inflow to Ethiopia averaged at $\$ 88.5$ million every year for two decades with the largest increase for 3 of the years (2003, 2006 and 2013). But the dominant trend in the flow is such that it kept declining from 2008 onwards except for 2013 and to some extent, 2015.

FDI inflow as a ratio of Ethiopia's GDP is indicated in Table 4. It showed that the average shares of FDI to GDP were $0.34 \%$. A similar share of FDI to trade for China shows at $6 \%$, meaning that FDI inflow is nearly $6 \%$ of the trade flows between Ethiopia

Table 4 Ethio-China FDI and trade ratios. Source: Own analysis from data

\begin{tabular}{|c|c|c|c|c|c|c|c|c|}
\hline Year & FDI & FDI Grw. & Trade & Trade Grw. & GDP Et & FDI/GDP & Trade/GDP & FDI/Trade \\
\hline 1997 & $1,320,362$ & & $55,266,554$ & & $8,589,211,391$ & 0.02 & 0.64 & 2.39 \\
\hline 1998 & $1,444,257$ & 9 & $68,321,262$ & 24 & $7,818,224,906$ & 0.02 & 0.87 & 2.11 \\
\hline 1999 & $3,451,377$ & 139 & $77,797,482$ & 14 & $7,700,833,482$ & 0.04 & 1.01 & 4.44 \\
\hline 2000 & 648,026 & -81 & $97,727,568$ & 26 & $8,242,392,104$ & 0.01 & 1.19 & 0.66 \\
\hline 2001 & $3,036,636$ & 369 & $141,353,874$ & 45 & $8,231,326,017$ & 0.04 & 1.72 & 2.15 \\
\hline 2002 & 924,502 & -70 & $152,863,348$ & 8 & $7,850,809,498$ & 0.01 & 1.95 & 0.6 \\
\hline 2003 & $16,524,151$ & 1,687 & $320,521,920$ & 110 & $8,623,691,300$ & 0.19 & 3.72 & 5.16 \\
\hline 2004 & $51,352,386$ & 211 & $382,649,760$ & 19 & $10,131,187,261$ & 0.51 & 3.78 & 13.42 \\
\hline 2005 & $14,442,218$ & -72 & $595,882,605$ & 56 & $12,401,139,454$ & 0.12 & 4.81 & 2.42 \\
\hline 2006 & $155,663,396$ & 978 & $711,226,707$ & 19 & $15,280,861,835$ & 1.02 & 4.65 & 21.89 \\
\hline 2007 & $243,909,464$ & 57 & $1,206,409,545$ & 70 & $19,707,616,773$ & 1.24 & 6.12 & 20.22 \\
\hline 2008 & $215,435,436$ & -12 & $1,831,054,517$ & 52 & $27,066,912,635$ & 0.8 & 6.76 & 11.77 \\
\hline 2009 & $149,719,858$ & -31 & $2,131,524,847$ & 16 & $32,437,389,116$ & 0.46 & 6.57 & 7.02 \\
\hline 2010 & $79,903,546$ & -47 & $2,290,298,528$ & 7 & $29,933,790,334$ & 0.27 & 7.65 & 3.49 \\
\hline 2011 & $65,486,788$ & -18 & $1,998,306,081$ & -13 & $31,952,763,089$ & 0.2 & 6.25 & 3.28 \\
\hline 2012 & $40,589,915$ & -38 & $2,748,734,678$ & 38 & $43,310,721,414$ & 0.09 & 6.35 & 1.48 \\
\hline 2013 & $368,313,058$ & 807 & $3,261,319,185$ & 19 & $47,648,211,133$ & 0.77 & 6.84 & 11.29 \\
\hline 2014 & $105,035,618$ & -71 & $5,474,580,081$ & 68 & $55,612,228,234$ & 0.19 & 9.84 & 1.92 \\
\hline 2015 & $190,307,136$ & 81 & $6,378,002,519$ & 17 & $64,464,547,915$ & 0.3 & 9.89 & 2.98 \\
\hline 2016 & $62,259,013$ & -67 & $5,444,103,219$ & -15 & $72,374,224,249$ & 0.09 & 7.52 & 1.14 \\
\hline Total & $1,769,767,143$ & & $35,367,944,280$ & & $519,378,082,140$ & 6.39 & 98.14 & 119.83 \\
\hline Avrg & $88,488,357$ & & $1,768,397,214$ & & 25968904107 & 0.3195 & 4.91 & 5.99 \\
\hline Av.Gr. & 209.3 & 202 & & 30 & & & & \\
\hline
\end{tabular}


and China. The trade to GDP ratio is relatively larger as it has $6.8 \%$ of the country's GDP (Table 4).

Table 5 shows the number of licensed Chinese projects at different levels viz- preimplementation, implementation and operational stages, totalling 1294 in number (Table 5).

From the table, we can see that 310 projects $(24 \%)$ were at pre-implementation stage, $183(14 \%)$ at implementation stage and $801(62 \%)$ of the projects at operation stage. The total capital registered for the 801 projects in operation was $\$ 2.44$ billion calculated at Average Official Exchange Rate for the period. The projects at operation created 152,987 permanent and 79,170 temporary employments for labour. Table 6 shows the sectoral distribution of Chinese FDI in Ethiopia and the status of operation for years 1997-2016 (Table 6).

The FDI projects participated in more than 9 different sectors but the lion share of the projects $(68.86 \%)$ were engaged into manufacturing sector followed by construction (12.78\%), real estate and equipment rent (11.67\%) and Hotels (3.48\%). The capital flows for the period indicate a sum of 2.9 billion USD.

Table 7 made similar analysis of the Chinese FDI projects regional distribution (Table 7).

The FDI projects are distributed at 7 regional states and 2 city administrations including the capital city Addis Ababa. There are a large number of the projects with a multiregional engagement.

Table 5 Licensed total Chinese FDI projects by year and status. Source: Ethiopian Investment Commission with further analysis

\begin{tabular}{|c|c|c|c|c|c|c|c|}
\hline \multirow[t]{2}{*}{ Year } & \multirow{2}{*}{$\begin{array}{l}\text { Implementation } \\
\text { No of projs }\end{array}$} & \multicolumn{4}{|l|}{ Operation } & \multirow{2}{*}{$\begin{array}{l}\text { Pre- } \\
\text { implementation } \\
\text { No of projs }\end{array}$} & \multirow{2}{*}{$\begin{array}{l}\text { Tgotal } \\
\text { no of projs }\end{array}$} \\
\hline & & No of projs & Capital in \$ & Perm Empl. & Temp Empl. & & \\
\hline 1998 & & 1 & $1,581,108$ & 54 & 8 & & 1 \\
\hline 1999 & & 1 & $4,085,201$ & 14 & 40 & & 1 \\
\hline 2000 & & 1 & 747,893 & 68 & 0 & & 1 \\
\hline 2001 & & 2 & $3,234,549$ & 310 & 0 & & 2 \\
\hline 2002 & & 1 & 963,613 & 30 & 0 & & 1 \\
\hline 2003 & 3 & 19 & $16,796,982$ & 707 & 485 & 1 & 23 \\
\hline 2004 & 5 & 19 & $51,745,368$ & 1193 & 2228 & 1 & 25 \\
\hline 2005 & 3 & 28 & $14,553,796$ & 733 & 943 & 2 & 33 \\
\hline 2006 & 4 & 51 & $156,719,454$ & 6151 & 7703 & 1 & 56 \\
\hline 2007 & 6 & 75 & $252,235,301$ & 3245 & 5814 & & 81 \\
\hline 2008 & 6 & 85 & $237,715,463$ & 8132 & 14,378 & 3 & 94 \\
\hline 2009 & 16 & 62 & $196,582,002$ & 3166 & 3670 & 1 & 79 \\
\hline 2010 & 11 & 44 & $119,935,138$ & 2587 & 2095 & & 55 \\
\hline 2011 & 6 & 34 & $93,945,332$ & 3301 & 2105 & 4 & 44 \\
\hline 2012 & 5 & 55 & $49,870,560$ & 2191 & 738 & 25 & 85 \\
\hline 2013 & 11 & 70 & $405,942,643$ & 6783 & 6297 & 40 & 121 \\
\hline 2014 & 22 & 48 & $116,226,302$ & 2901 & 1548 & 18 & 88 \\
\hline 2015 & 26 & 84 & $210,194,372$ & 5871 & 2416 & 29 & 139 \\
\hline 2016 & 22 & 64 & $69,065,068$ & 9254 & 6572 & 39 & 125 \\
\hline 2017 & 28 & 53 & $433,527,002$ & 95,231 & 22,051 & 69 & 150 \\
\hline 2018 & 9 & 4 & $6,546,961$ & 1065 & 79 & 77 & 90 \\
\hline Total & 183 & 801 & $2,442,214,107$ & 152,987 & 79,170 & 310 & 1294 \\
\hline
\end{tabular}




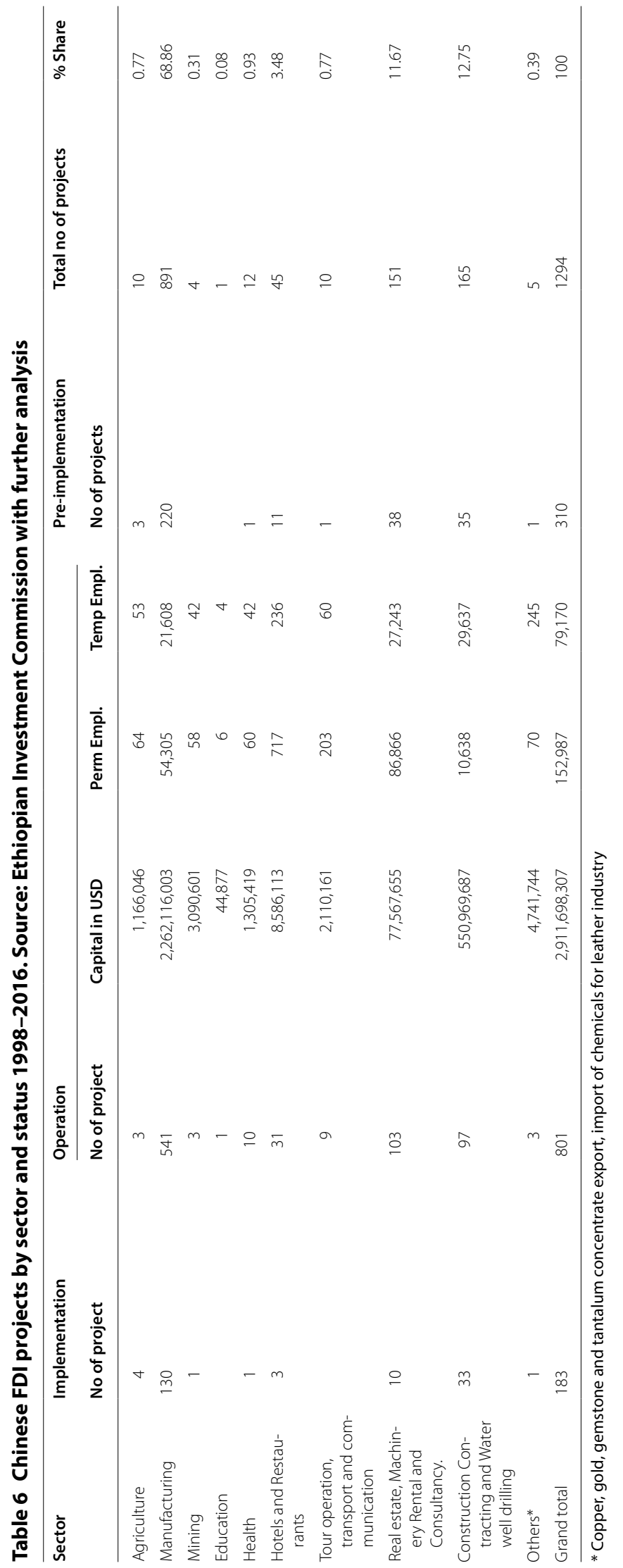


Table 7 Chinese investment projects by region and status. Source: Author's analysis from Ethiopian Investment Commission data

\begin{tabular}{|c|c|c|c|c|c|c|c|c|}
\hline \multirow[t]{2}{*}{ Region } & \multirow{2}{*}{$\begin{array}{l}\text { Implementation } \\
\text { No of Proj. }\end{array}$} & \multicolumn{4}{|c|}{ Operation } & \multirow{2}{*}{$\begin{array}{l}\text { Pre- } \\
\text { implementation } \\
\text { No of Proj }\end{array}$} & \multirow{2}{*}{$\begin{array}{l}\text { Total } \\
\text { no of proj. }\end{array}$} & \multirow[t]{2}{*}{ \% Share } \\
\hline & & $\begin{array}{l}\text { No } \\
\text { of Proj. }\end{array}$ & $\begin{array}{l}\text { Capital } \\
\text { in USD }\end{array}$ & $\begin{array}{l}\text { Perm } \\
\text { Empl. }\end{array}$ & $\begin{array}{l}\text { Temp } \\
\text { Empl. }\end{array}$ & & & \\
\hline $\begin{array}{l}\text { Addis } \\
\text { Ababa }\end{array}$ & 78 & 471 & $1,354,642,168$ & 30,408 & 38,646 & 157 & 706 & 54.56 \\
\hline Afar & & 2 & 152,413 & 5 & 35 & & 2 & 0.15 \\
\hline Amhara & 11 & 12 & $129,188,992$ & 3458 & 1244 & 36 & 59 & 4.56 \\
\hline B.Gumze & & & & & & 4 & 4 & 0.31 \\
\hline $\begin{array}{l}\text { Dire } \\
\text { Dawa }\end{array}$ & 3 & 7 & $43,688,738$ & 81,097 & 20,273 & 2 & 12 & 0.93 \\
\hline Gambella & & 1 & 393,480 & 10 & 100 & 2 & 3 & 0.23 \\
\hline $\begin{array}{l}\text { Multire- } \\
\text { gional }\end{array}$ & 3 & 35 & $34,343,014$ & 1731 & 2198 & & 38 & 2.94 \\
\hline Oromia & 84 & 262 & $1,326,923,201$ & 32,302 & 16,188 & 106 & 452 & 34.93 \\
\hline SNNPR & 3 & 7 & $13,043,946$ & 3866 & 423 & 3 & 13 & 1.00 \\
\hline Tigray & 1 & 4 & $9,322,354$ & 110 & 63 & & 5 & 0.39 \\
\hline $\begin{array}{l}\text { Grand } \\
\text { total }\end{array}$ & 183 & 801 & $2,911,698,307$ & 152,987 & 79,170 & 310 & 1294 & 100 \\
\hline
\end{tabular}

The share of the 1294 projects distribution across the regions and cities indicate that 706 (54.56\%) reside in the capital Addis Ababa, and 452 (34.9\%) of the projects reside in Oromiya regional state, the neighbouring region to the capital. The third concentration goes to Amhara regional state with 59 (4.56\%) share and multi-regional projects were 38 (2.94\%) of the share. The distribution patterns show that there is skewed nature following location advantage and road accessibility for market.

Table 8 Fixed effects estimation for Ethio-India FDI inflow. Source: own estimation

\begin{tabular}{|c|c|c|c|c|c|c|c|c|}
\hline Lfdiflow & Coef. & & St. Err & & $t$ value & $p$ value & & Sig \\
\hline loer & 13.427 & & 5.631 & & 2.38 & 0.097 & & * \\
\hline lgdpet & 3.072 & & 1.038 & & 2.96 & 0.060 & & * \\
\hline lettrade & 4.595 & & 1.109 & & 4.14 & 0.026 & & ** \\
\hline Ifornpopn & -185.618 & & 56.753 & & -3.27 & 0.047 & & $* *$ \\
\hline lgdppcfn & 13.138 & & 5.068 & & 2.59 & 0.081 & & $*$ \\
\hline Irelinterst & 0.241 & & 0.100 & & 2.42 & 0.094 & & * \\
\hline letgrowth & -0.213 & & 0.213 & & -1.00 & 0.392 & & \\
\hline Iresource & 1.163 & & 1.100 & & 1.06 & 0.368 & & \\
\hline Icredit & -2.676 & & 0.539 & & -4.96 & 0.016 & & ** \\
\hline Ifdiopen & 7.682 & & 1.899 & & 4.04 & 0.027 & & $* *$ \\
\hline Constant & 3561.705 & & 1097.072 & & 3.25 & 0.048 & & $* *$ \\
\hline Mean-dependent var & & 16.348 & & SD-dependent var & & & 1.676 & \\
\hline R-squared & & 0.994 & & Number of obs & & & 14.000 & \\
\hline F-test & & 49.666 & & Prob $>F$ & & & 0.004 & \\
\hline Akaike crit. (AIC) & & 3.530 & & Bayesian crit. (BIC) & & & 10.560 & \\
\hline
\end{tabular}

${ }^{* * *} p<0.01, * * 0<0.05, * 0<0.1$ 


\subsection{Econometric analysis}

In Ethio-India bilateral economic relation, one of the major channels linking both partner countries is the Foreign Direct Investment flows. Assessment of the last two-decade relationship of Ethiopia with India along this channel of interest indicates that India is 6th largest stakeholder in FDI inflow to Ethiopia with 576 registered projects in the duration of time indicated.

The following section examines the factors governing Ethiopia's FDI relation with India and analyzes the direction of influence and the magnitude for the factors affecting the variation in FDI inflow across years. Hence, fixed effects estimation technique is employed to estimate the variation in the flow of the dependent variable, log of FDI inflow from India over a set of 10 explanatory variables. The variables are all in their log forms.

The estimation took the following form:

$$
\begin{aligned}
\text { Lfdinflow }= & \beta_{1} \mathrm{i}+\beta_{2} \text { lnoer }+\beta_{3} \text { lngdpet }+\beta_{4} \text { lnettrade }+\beta_{5} \text { lnfornpop } \\
& +\beta_{6} \text { lnpcgdpforn }+\beta_{7} \text { lnrealinterest }+\beta_{8} \text { lnetgrowth }+\beta_{9} \text { Inresource } \\
& +\beta_{10} \text { lncredit }+\beta_{11} \text { lnfdiopen }+ \text { Uit. }
\end{aligned}
$$

Table 8 shows the Fixed Effects estimation result for log of FDI inflow from India. Out of 10 explanatory variables, 8 were found significant at different levels and each one of them has been explained below. The overall R-square from the fixed effects estimation shows that $99.4 \%$ of the variation is explained by the regressors (Table 8 ).

Table 8 indicates that the eight significant variables list that includes OER, GDP of Ethiopia, and Ethiopia's trade flow, population size of foreign partner (India), GDPPC of foreign partner (India), real interest rate, credit access and FDI openness. Discussion of each of these significant variables is done next.

The estimation result can be put as follows:

$$
\begin{aligned}
\text { Lfdinflow }= & 3561+13.43 \text { lnoer }+3.07 \text { lngdpet }+4.6 \text { lnettrade }-186 \text { lnfornpop } \\
& +13.1 \text { lnpcgdpforn }+0.24 \text { lnrealinterest }-2.68 \text { lncredit } \\
& +7.68 \text { lnfdiopen }+ \text { Uit. }
\end{aligned}
$$

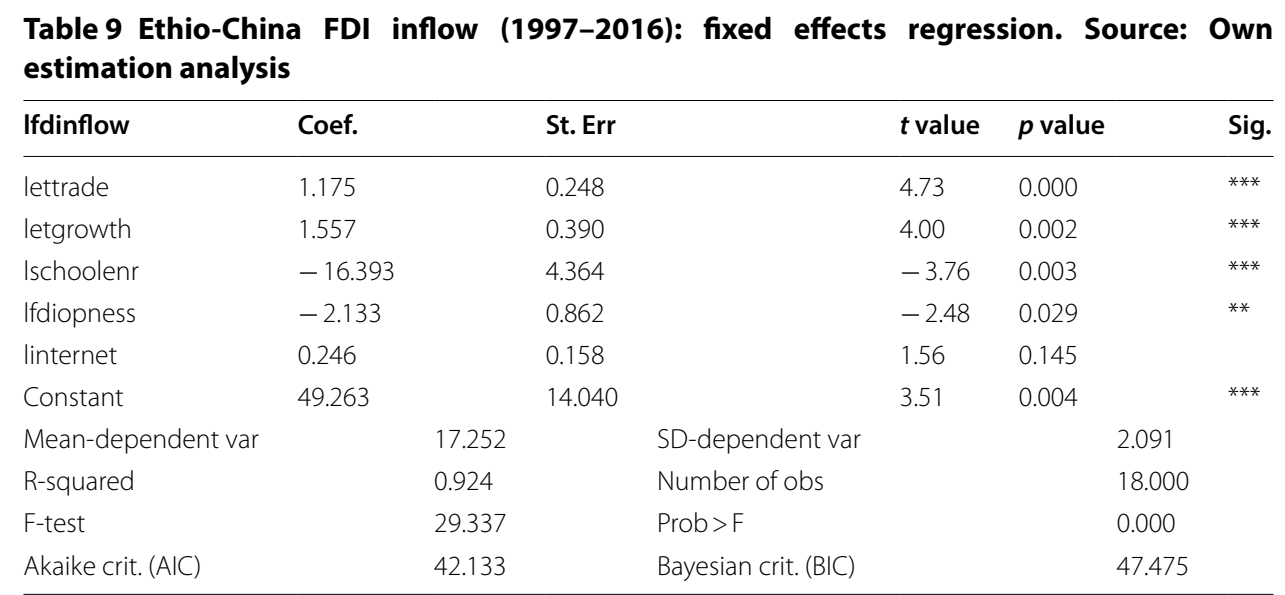

*** $p<0.01,{ }^{* *} p<0.05, * 0<0.1$ 
This study analyzes factors governing FDI inflow from China to Ethiopia for the past two decades. Fixed effects estimation of the FDI inflow over a set of independent variables is done based on panel data. After several trials, five explanatory variables were selected for the estimation and the output of the regression is indicated in Table 9. Major list of regressors used is indicated in Appendix.

Of the explanatory variables, four of them were found significant; three of which at $1 \%$ level and one at 5\% level. Two of the significant variables viz FDI openness and secondary school enrolment showed negative influence on FDI inflow from China, where as Ethiopia trade flow with China and Ethiopia's GDP growth showed positive impact on FDI flows. The estimation result is put as follows (Table 9).

Lfdinfflow $=49.3+1.175$ lettrade +1.56 letgrowth -16.4 lsecscholenr -2.13 lfdiopeness + Uit.

\subsubsection{Result and discussion on Ethio-India FDI flows}

India's population size This variable is found significant at $5 \%$ level with highest share of its impact on FDI inflow. It is found negative in its impact on FDI inflow to Ethiopia. An increase in the size of India's population by $1 \%$ would result in a decline in FDI inflow from India to Ethiopia by $186 \%$. This indicates that more population size in India would mean more market at home and hence FDI outflow from India declines as long as firms' demand for market is satisfied at home. This shows that Indian firms are going out for market access.

Official Exchange Rate (OER) OER has shown significance at $10 \%$ level and is positively influencing the FDI inflow. An increase in official exchange rate by 1 unit would result in increased flow of FDI by $13.4 \%$. This indicates that when domestic currency is devaluated, investment costs would decline for foreign firms and export competitiveness for their products would increase in the world markets. This finding is in line with the results of other studies which are summarized in literature section of this study. The studies showed role of instability in OER resulting in negative FDI flows.

GDP of Ethiopia Ethiopia's GDP is found significant in explaining the inflow of FDI at $10 \%$ level. A 1\% increase in Et-GDP results in an increase of FDI inflow by 3\%. The direction of influence is found positive, i.e., as Ethiopia's GDP grows more FDI inflow would occur as the growth in GDP creates more income and access for market for the FDI project outputs. It would also mean that countries with bigger GDP size would have more FDI inflows. This finding is similar with the findings of other studies as well as the theoretical predictions of the gravity model. In studies identified so far, the GDP size has a positive role in increasing FDI flows.

Ethiopia's trade flow Estimation from Table 8 indicates a positive relationship in inflow of trade and FDI in case of Ethiopia and India bilateral relation. Trade flow is found significant at 5\% level and positive in its direction of influence. The Beta value indicates that a $1 \%$ increase in trade flows increases FDI inflow to Ethiopia by $4.6 \%$. This relationship indicates that trade and FDI flow are in association in case of Ethiopia and India bilateral relation. 
GDP PC of India PC GDP of a partner country, India, in our case, is found significant at $10 \%$ level. The Beta value indicates that a $1 \%$ increase in PC of India would increase the FDI inflow to Ethiopia by $13.14 \%$. As India's income increases, there would be a tendency for Indian FDI outflow as this would create capacity for the entrepreneurs to invest abroad. This factor is found to influence the flow of FDI positively in similar studies but the GDP PC growth of the host country showed a negative impact in FDI flows according to other studies identified in literature section.

Real interest rate This variable being an indicator of the profit opportunity for FDI capital flows would have impact on the flow. In our case, real interest rate is found significant at $10 \%$ level and the direction of influence was positive. Meaning that, as real interest rate increases by $1 \%$, the flow of FDI to Ethiopia would increase by $0.24 \%$ points. Though the impact of this explanatory variable is marginal, the direction of influence is as per the prediction from earlier studies.

Credit access Domestic credit access to private sector participation in Ethiopia would create increased participation of the private actors and hence, would result in reduced demand for foreign direct investment flow.

According to the fixed effects estimation on Table 8, credit access has negative impact on FDI inflow from India and the Beta value shows that it is significant at $5 \%$ level. A $1 \%$ increase in credit access results in $2.68 \%$ decline in FDI inflow. This implies that any increase in the credit access for domestic investors would result in substitution effect on the part of incoming FDI from foreign partner. This would seem feasible in the short run when private sector capacity is weak both in finance and technical capacity in earlier phases. With increased capacity and technical knowhow, domestic firms would start to be competitive and substitute the FDI to some degree. But the long-run effect would be such that, once domestic needs for basic goods and services are met, international market access would demand more competiveness which would again creates appropriate collaborative effort from experienced multinational corporations.

FDI openness This is one of the significant explanatory variables influencing positively the inflow of FDI from India with the level of significance at $5 \%$ level. Beta value from the same table indicates that a $1 \%$ increase in FDI openness would result in an increase in FDI inflow by $7.68 \%$. This means that the more open an Ethiopian economy for FDI, the larger would the inflow be for the Indian firms to join investment in Ethiopia.

\subsubsection{Ethio-China FDI flows}

Log of Ethiopia's trade is significant at $1 \%$ level and positive in its direction of influence on FDI inflow from China. The beta value shows that a $1 \%$ increase in Ethiopia's trade with China would result in $1.175 \%$ rise in FDI flows. This means that both trade flow and FDI flow have positive relationship in Ethio-China bilateral economic relation for last 2 decades. The direction of influence for ettrade is positive and is as per the prediction.

GDP growth affected FDI inflow positively. The beta estimated value shows that a $1 \%$ increase in Ethiopia's growth rate would result in $1.56 \%$ rise in FDI inflow. This would mean 
Table 10 Comparing the FDI inflow determinants Source: Own analysis

\begin{tabular}{llll}
\hline No & Explanatory variables & Ethio-India & Ethio-China \\
\hline 1 & Letgrowth & & $1.56(1 \%)$ \\
2 & Lettrade & $4.59(5 \%)$ & $1.175(1 \%)$ \\
3 & Lforeignpopn & $-185.6(5 \%)$ & \\
4 & Lresource & $3.07(10 \%)$ & \\
5 & Lgdpof Ethiopia & $13.14(10 \%)$ & \\
6 & Lgdppcforeign & $0.24(10 \%)$ & $-2.13(5 \%)$ \\
7 & Lrealint rate & $-2.68(5 \%)$ & $-16.39(1 \%)$ \\
8 & Lcredit & $7.68(5 \%)$ & 92.4 \\
9 & Lfdiopeness & $13.43(10 \%)$ & \\
10 & Lsecschoolenrol & & \\
\hline
\end{tabular}

that the fast-growing economies can attract more FDI's compared to slow growing ones. This factor is seen to have similar impact in FDI inflow in case of other studies, which is again in line with the theoretical prediction on gravity model estimation.

A $1 \%$ increase in secondary education enrolment would decrease FDI inflow from China by $16.4 \%$. The variable might have positive or negative impact in FDI inflow depending on the demand type for the labour. If skilful labour is the requirement, FDI inflow is supposed to increase with increased enrolment. But if the FDI is a low-end one, demanding more and more labour, increased enrolment would reduce the inflow, as it results in shortage of supply of labour.

FDI openness is significance at $5 \%$. The beta value also shows that a $1 \%$ increase in FDI openness rate would result in a decline of FDI inflow by $2.13 \%$. This result is unpredicted and the justification is not direct forward. However, it indicates that openness would result in declining flow of FDI from China as it would result in increasing flow from other emerging partners that would compete with China's strategic position in the country.

\subsection{FDI comparison}

Comparison of explanatory variables for FDI inflow to Ethiopia from the two partners are shown in Table 10. Of the 13 explanatory variables identified as regressors explaining FDI inflow to Ethiopia for the last 20 years, India shared two of the four explanatory variables in common with China (ettrade and FDI openness). This implies that the attracting factors for China's FDI inflow were different from those which were explaining the relation for Ethiopia-India FDI inflow (Table 10).

It can be concluded that each pair of countries could have at least one uniquely governing explanatory variable for FDI flow in its relation with Ethiopia during the 20-year period. Hence, a separate regression of the above sort is essential to identify country-specific explanatory variables in bilateral relation.

\section{Summary and conclusions}

\subsection{Summary on explanatory variables}

India is the 6th important origin of FDI inflow to Ethiopia with its share of $5.84 \%$ and 576 projects for the last two decades. FDI inflow from India grew at $82 \%$ on average and 
nearly $70 \%$ of the FDI is engaged in manufacturing and construction, followed by $17 \%$ agricultural engagement. All sorts of service trade constituted 13\% share.

In general, four variables such as India's population size, Ethio-India trade flows, credit access and FDI openness are found explaining the Ethio-India FDI relation followed by four other variables such as OER, GDP of Ethiopia, GDP PC of India, and real interest rate in Ethiopia which were found marginally significant in explaining the FDI relation of Ethiopia with India for the last 20 years.

FDI inflow from China is governed by factors such as Ethio-China trade flow, Ethiopia's GDP growth rate, secondary school enrolment in Ethiopia, and FDI openness. The traditional explanatory variable such as resource rent was not significant in explaining FDI in flow from China. The flow of FDI and trade are positively related in Ethio-China economic relation showing that Chinese FDI flows are linked with trade flows and both relate positively and are integrated. Major drivers for FDI inflow were market access and cheap labour in the context of Ethiopia rather than resource rent.

\subsection{Conclusions}

Factors governing the flow of Indian FDI to Ethiopia were Ethio-India trade flows (+ve), India's population size ( $-\mathrm{ve})$, GDP of Ethiopia (+ve), GDP PC of foreign partner (India) $(+\mathrm{ve})$, real interest rate $(+\mathrm{ve})$, credit access $(-\mathrm{ve})$ and FDI openness $(+\mathrm{ve})$. Of the 8 explanatory variables, India shared two with China (ettrade, and FDI openness).

Factors governing Chinese FDI inflow include variables such as Ethiopia's growth $(+\mathrm{ve})$, ettrade (+ve), FDI openness (-ve), and secondary school enrolment ( $-v e)$. Of the four explanatory variables, China shared two of them (ettrade and FDI openness) with India.

Both China and India are focussing on manufacturing sector. Moreover, India focuses more on agriculture and China on construction sector. India has some degree of involvement on IT, education and health sectors though marginal it is.

China's approach in FDI flow patterns differs significantly in its nature and size. The two bilateral partners shared only few of the variables commonly explaining their flows in the two-decade period.

We can conclude that FDI from India is responsive to macroeconomic variables such as OER, real interest rate and liberalization measures such as trade openness in Ethiopia. Growth of India's population and GDP would increase Ethio-India trade and Ethiopia's per-capita growth has similar effect.

FDI and trade flows from China are positively related to one another. Increased secondary school enrolment in Ethiopia discourages China's FDI flows. This indicates that Chinese firms demand for cheap labour for their manufacturing industries in Ethiopia. When the labour quality increases through education, associated cost of employing labour would increase and hence, discourage FDI inflow from China. Government expenditure discourages China's and India's FDI flows. The traditional explanatory variable, a resource rent, was not found significant in explaining FDI in flow from China and India.

Ethio-India's bilateral relation analysis reveals that trade and openness to FDI are explaining the relationship better for FDI inflow with Ethiopia. 
Policy makers in Ethiopia can focus on macroeconomic reform in case of the country's relation with India whereas they focus on maintaining cheap labour cost, GDP growth and trade transactions with China so as to increase the flow of Chinese FDI to the country.

\section{Acknowledgements}

Not applicable.

Authors' contributions

DE contributed the data processing and the analysis of the manuscript. KR contributed in handled the editing and proof reading on the all drafts of the manuscript. Both authors read and approved the final manuscript.

\section{Funding}

No funding claim from any source.

\section{Availability of data and materials}

Available.

\section{Competing interests}

No competing interests of any sort.

\section{Author details}

${ }^{1}$ Andhra University, Visakhapatnam, Andhra Pradesh, India. ${ }^{2}$ Department of Economics, Hawassa University, Awassa, Ethiopia. ${ }^{3}$ Agro-Economic Research Center, Department of Economics, Andhra University, Visakhapatnam, India.

\section{Appendix}

See Table 11.

Table 11 FDI explanatory variables and data source

\begin{tabular}{|c|c|c|c|}
\hline Dependent variable & Explanatory variables & Expected sign & Source of data \\
\hline \multirow[t]{11}{*}{ FDI inflow* } & 1.GDP growth rate & Positive & World Bank Country Statistics, 1960-2016 \\
\hline & 2. Labour availability & Positive & $\begin{array}{l}\text { World Development Indicators } \\
\text { https://data.worldbank.org/indicator }\end{array}$ \\
\hline & 3. Trade openness & Positive & $\begin{array}{l}\text { COMSTAT DATA HUB } \\
\text { http://comstat.comesa.int//NTGRA2016/integ } \\
\text { ration-indicators-2016?tsld =1000220 }\end{array}$ \\
\hline & $\begin{array}{l}\text { 4. Secondary school enrol- } \\
\text { ment/WF quality }\end{array}$ & Positive & $\begin{array}{l}\text { The World Bank } \\
\text { https://data.worldbank.org/indicator }\end{array}$ \\
\hline & 5. Per capita difference & $\begin{array}{l}\text { Positive/nega- } \\
\text { tive }\end{array}$ & World Bank Country Statistics, 1960-2016 \\
\hline & 6. OER & $\begin{array}{l}\text { Positive/nega- } \\
\text { tive }\end{array}$ & $\begin{array}{l}\text { Ethiopia Data Portal/World Development } \\
\text { indicators } \\
\text { http://ethiopia.opendataforafrica.org/mbhpa } \\
\text { n/world-development-indicators-wdi- } \\
\text { november-2014 }\end{array}$ \\
\hline & $\begin{array}{l}\text { 7. Population size home- } \\
\text { host }\end{array}$ & Positive & $\begin{array}{l}\text { Ethiopia Data Portal/World Development } \\
\text { indicators } \\
\text { http://ethiopia.opendataforafrica.org/mbhpa } \\
\text { n/world-development-indicators-wdi- } \\
\text { november-2014 }\end{array}$ \\
\hline & $\begin{array}{l}\text { 8. Market size of the host/ } \\
\text { country's GDP }\end{array}$ & Positive & World Bank Country Statistics, 1960-2016 \\
\hline & $\begin{array}{l}\text { 9. Government size/con- } \\
\text { sumption expenditure }\end{array}$ & $\begin{array}{l}\text { Positive/nega- } \\
\text { tive }\end{array}$ & $\begin{array}{l}\text { COMSTAT DATA HUB } \\
\text { http://comstat.comesa.int/hsyndwf/socio } \\
\text {-economic-database-of-africa-1960-2050 }\end{array}$ \\
\hline & $\begin{array}{l}\text { 10. Inflation, consumer price } \\
\text { annual }\end{array}$ & Negative & $\begin{array}{l}\text { The World Bank Data } \\
\text { https://data.worldbank.org/indicator }\end{array}$ \\
\hline & 11. Natural resource rent & Positive & $\begin{array}{l}\text { Ethiopia Data Portal/World Development } \\
\text { indicators } \\
\text { http://ethiopia.opendataforafrica.org/mbhpa } \\
\text { n/world-development-indicators-wdi- } \\
\text { november-2014 }\end{array}$ \\
\hline
\end{tabular}


Table 11 (continued)

\begin{tabular}{|c|c|c|c|}
\hline Dependent variable & Explanatory variables & Expected sign & Source of data \\
\hline & 12. Internet users & Positive & $\begin{array}{l}\text { Source: Internet Live Stats (www.InternetLi } \\
\text { veStats.com) } \\
\text { Elaboration of data by International Telecom- } \\
\text { munication Union (ITU), World Bank, and } \\
\text { United Nations Population Division. } \\
\text { http://www.internetlivestats.com/internet- } \\
\text { users/ethiopia/ }\end{array}$ \\
\hline & 13.GDP PC home-host & Positive/negat. & World Bank Country Statistics, 1960-2016 \\
\hline & $\begin{array}{l}\text { 14. Real effective exchange } \\
\text { rate }\end{array}$ & Negative & $\begin{array}{l}\text { http://bruegel.org/publications/datasets/ } \\
\text { real-effective-exchange-rates-for-178-count } \\
\text { ries-a-new-database/ }\end{array}$ \\
\hline & 15. Real interest rate & Positive & $\begin{array}{l}\text { World Development Indicators } \\
\text { https://data.worldbank.org/indicator/FR.INR. } \\
\text { RINR?locations=ET\&view=chart }\end{array}$ \\
\hline & $\begin{array}{l}\text { 16. Political and institutional } \\
\text { risk }\end{array}$ & Negative & $\begin{array}{l}\text { The World Bank Data Catalogue } \\
\text { https://datacatalog.worldbank.org/dataset/ } \\
\text { worldwide-governance-indicators }\end{array}$ \\
\hline & 17. Rule of law & Positive & $\begin{array}{l}\text { The World Bank Data Catalogue } \\
\text { https://datacatalog.worldbank.org/dataset/ } \\
\text { worldwide-governance-indicators }\end{array}$ \\
\hline & 18. Corruption & Negative & $\begin{array}{l}\text { The World Bank Data Catalogue } \\
\text { https://datacatalog.worldbank.org/dataset/ } \\
\text { worldwide-governance-indicators }\end{array}$ \\
\hline & $\begin{array}{l}\text { 19. Domestic credit/financial } \\
\text { development }\end{array}$ & Positive & $\begin{array}{l}\text { COMSTAT DATA HUB/WB } \\
\text { http://comstat.comesa.int/cxaujud/world } \\
\text {-development-indicators-wdi }\end{array}$ \\
\hline & 20. Effectiveness & Positive & $\begin{array}{l}\text { The World Bank Data Catalogue } \\
\text { https://datacatalog.worldbank.org/dataset/ } \\
\text { worldwide-governance-indicators }\end{array}$ \\
\hline & 21. Regulatory framework & Positive & $\begin{array}{l}\text { The World Bank Data Catalogue } \\
\text { https://datacatalog.worldbank.org/dataset/ } \\
\text { worldwide-governance-indicators }\end{array}$ \\
\hline & 22. Et-growth rate & Positive & World Bank Country Statistics, 1960-2016 \\
\hline & 23. Bilateral trade flow & Positive/neg' & Ministry of Trade, Ethiopia \\
\hline & 24. FDI openness & Positive & $\begin{array}{l}\text { COMSTAT DATA HUB } \\
\text { http://comstat.comesa.int/INTGRA2016/integ } \\
\text { ration-indicators-2016?tsld }=1000220\end{array}$ \\
\hline
\end{tabular}

* FDI flow data from the Ethiopian Investment Commission

Received: 20 August 2019 Revised: 5 January 2020 Accepted: 11 April 2020

Published online: 23 April 2020

\section{References}

Alemayehu G, Atnafu GM (2011) Impact of China-Africa Investment Relations: Case Study of Ethiopia. Addis Ababa University, IAES Working Paper Serious no. A04

Anderson JE (1979) A theoretical foundation for the gravity equation. Am Econ Rev 69:106-116

Anne-Lise B (2014) Determinants of Chinese FDI in Africa: An econometric analysis. Master's Thesis, Department of Economics, University of Bergen

Asayegn D (2009) Chinese Investment in Ethiopia: Developmental Opportunity or Deepening China's new Mercantilism? http://www.aigaforum.com/articles/Chinese Investment in_Ethiopia_052009.htm

Bergstrand JH (1989) The generalised gravity equation, monopolistic competition, and the factor proportion theory in international trade. Rev Econ Stat 71:143-153

Davidova L (2012) Determinants of Austrian International Trade: econometric analysis based on the gravity model. Bachelor Thesis (BSc.) Charles University in Prague, Faculty of Social Sciences, Institute of Economic Studies, Prague (in Prague) 
Dawit T (2014) Analysis of Chinese FDI in SSA with a particular focus in Ethiopia. Ethiopian Journal of Business and EconomiCs (EJBE), 4 (FDI), 30

Deardorff A (1998) Determinants of bilateral trade: does gravity work in a classical world?. Centre for Research on Economic \& Social Theory, Michigan

Dejene MB (2016) Determinants of foreign direct investment in Ethiopia: time series evidence from 1991-2013. J Develop Areas 50(1):141-155

Dinh TTB, Nguyen VD, Hoang MC (2010) Applying GM to analyse trade Activities of Vietnam. http://www.freit.org/Worki ngPapers/Papers/TradePatterns/FREIT639.pdf

Eaton J, Kortum S (1997) Engines of growth: domestic and foreign sources of innovation. Japan World Econ 9:235-259

Eichengreen I (1998) The role of history in bilateral trade flows. In: The regionalization of the world economy. http://www. nber.org/chapters/c7819, p. 33-62)

Estrella GZH, Juliette MB (n.d.) Are estimation techniques neutral to estimate gravity equations? An application to the impact of EMU on third countries' exports. http://www.etsg.org/ETSG2009/papers/gomez.pdf

Gebregeorgis A (2016) Ethio-China economic relations: nature of China's Foreign Direct Investment in Ethiopia

Gedion GJ (2014) Development assistance from the South: comparative analysis of Chinese and Indian to Ethiopia. Chin Stud. 3(1):24-39

Green Econometrics (2002) Models for panel data (5th edition), Chapter 13 pp 310-366

Hui C (2005) Howard JW (2005) Controlling for heterogeneity in gravity models of trade and integration. Federal Reserve Bank St Louis Rev 87(1):49-63

Kinfu A et al (2010) The impact of Chinese investment in Africa. Int J Bus Manage 5(9):3

Krishna KJ (2002) A SUR-EC-AR system gravity model of trade. Working Paper, Department of Economics, University of Geneva, Geneva

Linnemann H (1966) An Econometric study of international trade flows. Holland Publishing, Amsterdam

Malancha C (2014) Ethiopia China economic relations: a classic Win-Win situation? World Rev Polit Econ 7(2):226-248

Nazgol G (2014) Chinese OFDI and private companies in Ethiopia: industrialization and employment opportunities. Lund University, Lund

Oguledo VI, Macphee CR (1994) Gravity Models: a reformulation and an application to discriminatory trade arrangements. Appl Econ 26:107-120

Peter E (2000) A note on proper econometric specification of gravity Equation. Austrian Institute of Economic research. https://EconPapers.repec.org/RePEc:eee:ecolet:v:66:y:2000:i:1:p:25-31

Prateeksha T (2015) Indian and Chinese FDI in Ethiopia: nature, impact, and challenges. DU J Undergrad Res Innov. 1(3):124-143

Salahuddin M, Islam R (2008) Factors affecting investment in developing countries: a panel data study. J Deve Areas 42(1):21-37

Santos S, Silvana T (2006) The log of gravity. Rev Econ Stat 88(4):641-658

Selamawit Berhe WK (2015) FDI and Economic Development in Ethiopia. M.Sc. Thesis in Applied Economics and Finance, Copenhagen Business School, November 2015 Characters: 179,157

Song H, Liu Z, Ping J (2001) Analysing the determinants of China's aggregate investment in the reform period. China Economic Review, vol 12. Elsevier, Amsterdam, pp 227-242

Tegegne G (2006) The developmental impact of China and India on Ethiopia with emphasis on small scale footwear producers. Paper prepared for OECD in the framework of "Development Impact of the economic ascendancy of China and India on other developing countries"September 2006

WB (2012) Chinese FDI in Ethiopia: A World Bank Survey Africa Region

World Bank Group (2016) Ethiopia's greater run, the growth acceleration and how to pace it. World Bank Group, Washington

Zarotiadis G (n.d.) FDI and International trade relations: a theoretical approach. https://www.etsg.org/ETSG2006/papers/ Zarotiadis.pdf

\section{Publisher's Note}

Springer Nature remains neutral with regard to jurisdictional claims in published maps and institutional affiliations. 